\title{
QuickScan macrofauna Sterkselsche Aa 2018
}

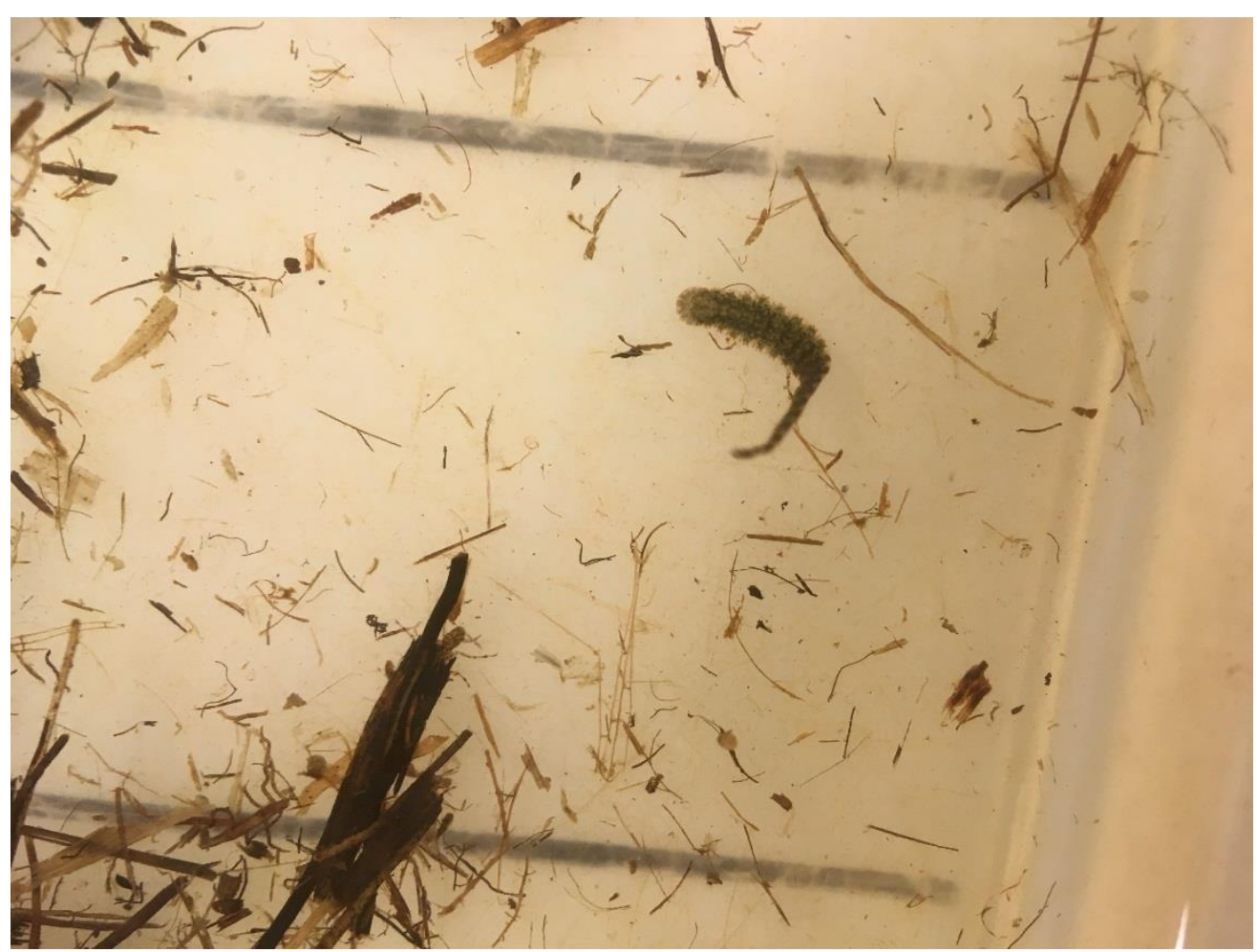

Ralf Verdonschot \& Piet Verdonschot

Notitie Zoetwatersystemen, Wageningen Environmental Research December 2019 


\section{Auteurs}

Ralf Verdonschot, Piet Verdonschot

\section{Opdrachtgever}

Waterschap de Dommel; contactpersoon Mark Scheepens

\section{Referaat}

Verdonschot, R.C.M., Verdonschot P.F.M. (2019) QuickScan macrofauna Sterkselsche Aa 2018. Notitie Zoetwatersystemen, Wageningen Environmental Research, Wageningen UR, Wageningen.

\section{Trefwoorden}

indicatoren, KRW, beoordelingssysteem, ecologische kwaliteit

\section{Beeldmateriaal}

Ralf Verdonschot

ISBN: 978-94-6395-259-0

DOI: $10.18174 / 510055$

(C) 2019 Wageningen Environmental Research, Wageningen UR

- Overname, verveelvoudiging of openbaarmaking van deze uitgave is toegestaan mits met duidelijke bronvermelding.

- Overname, verveelvoudiging of openbaarmaking is niet toegestaan voor commerciële doeleinden en/of geldelijk gewin.

- Overname, verveelvoudiging of openbaarmaking is niet toegestaan voor die gedeelten van deze uitgave waarvan duidelijk is dat de auteursrechten liggen bij derden en/of zijn voorbehouden.

Wageningen Environmental Research aanvaardt geen aansprakelijkheid voor eventuele schade voortvloeiend uit het gebruik van de resultaten van dit onderzoek of de toepassing van de adviezen 


\section{Inhoud}

1. Inleiding en doel 3

1.1 Achtergrond 3

1.2 Doel en producten 3

2. Methode 4

2.1 Bemonstering 4

2.2 Analyse 6

3. Resultaten 9

3.1 Taxonrijkdom op basis van de QSM 9

3.2 QSM preferentiescores 9

3.3 Vegelijking QSM preferentiescores en EKR KRW maatlatten 14

3.4 Vegelijking QSM beoordeling en de indicatortaxa Noord Brabant 15

3.5 Multivariate analyse QSM monsters en milieuvariabelen $\quad 15$

3.6 Bemonsteringsinspanning en kosten 18

4. Conclusies en aanbevelingen 19

5. Referenties 21 


\section{Inleiding en doel}

\subsection{Achtergrond}

Het waterschap de Dommel zoekt naar kosteneffectieve, ruimtelijk dekkende, diagnostische benaderingen om beeksystemen te beoordelen op basis van de macrofauna. Dit is ingegeven door de hoge kosten die het nemen en verwerken van macrofaunamonsters volgens de KRW methode met zich mee brengt. Een methode die mogelijk beter bij dit doel aansluit, is de QuickScan Macrofauna (QSM) methode. Deze methode is in ontwikkeling en voor het eerst toegepast voor stilstaande wateren bij waterschap Rivierenland (Keizer et al. 2013), gevolgd door een toepassing in de overige wateren van hoogheemraadschap Rijnland. In 2017 is de methode voor het eerst toegepast in stromende wateren, de Glanerbeek bij waterschap Vechtstromen. Door kleinere monsters te nemen en deze te determineren 'op het oog' hoogst zichtbare taxonomische niveau kunnen $85 \%$ van de kosten worden bespaard (Keizer et al., 2013). Met de QSM methode is het mogelijk een ruimtelijk meer representatief beeld te krijgen van de huidige ecologische toestand en op hoofdlijnen een diagnose te stellen van de belangrijkste sleutelfactoren.

\subsection{Doel en producten}

Het doel van dit project is om de haalbaarheid van de QSM-methode te toetsen op de Sterkselsche $\mathrm{Aa}$. Het systeem kent een grote ruimtelijke variabiliteit in termen van hydrologie, morfologie, waterkwaliteit en landgebruik en is als zodanig een mooi pilotgebied. Voor de Sterkselsche Aa heeft Waterschap de Dommel een beekherstel- en watersysteemherstelopgave. De bevindingen kunnen daarmee als basis dienen voor het nemen van de juiste maatregelen op de juiste plekken binnen het beeksysteem.

Het project resulteert in de volgende producten:

1. Inzicht in de ecologische kwaliteit van 24 meetpunten langs de Sterkselsche Aa op basis van de QSM methode.

2. Interpretatie van de verschillen tussen de meetlocaties en het verklaren van de variatie tussen de meetlocaties met behulp van sleutelfactoren op basis van de milieu- en habitatpreferenties van de aangetroffen taxa.

3. Vergelijking tussen de QSM en de KRW EKR scores voor 3 locaties waar beide beoordelingen zijn toegepast.

4. Vergelijking tussen de benodigde inspanning en kosten bij het nemen verwerken en determineren van QSM- en KRW-monsters. 


\section{Methode}

\subsection{Bemonstering}

In het voorjaar van 2018 is door Aquon de QSM methode toegepast op 24 punten langs de Sterkselsche Aa (Figuur 1). Op iedere monsterlocatie is een representatief beektraject van $10 \mathrm{~m}$ geselecteerd. In het traject is een representatief monster genomen van de belangrijkste habitats met een totale lengte van $0,5 \mathrm{~m}$ met een standaardmacrofaunanet. De habitatsamenstelling is gegeven in tabel 1. De monsters zijn in het laboratorium van Aquon uitgezocht en de taxa zijn genoteerd. Ze zijn gedetermineerd tot op familieniveau en in het geval van haften, steenvliegen en kokerjuffers (EPT) tot op genusniveau. Dit gebeurde op het oog of bij twijfelgevallen met behulp van een binoculair. In 2018 is alleen de aan- en afwezigheid van de taxa genoteerd; er is niet met abundantieklassen gewerkt.

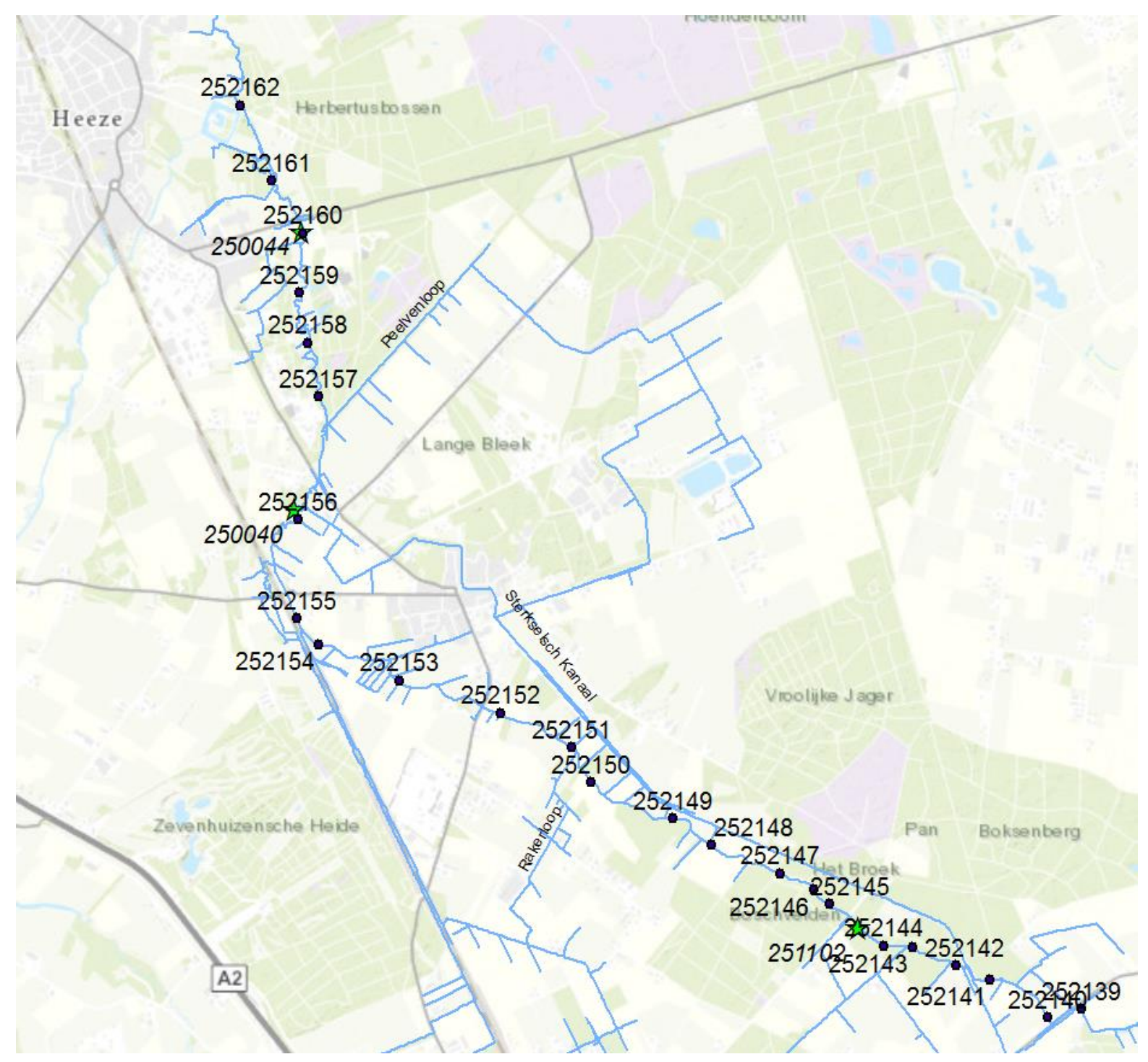

Figuur 1: Meetlocaties Sterkselsche Aa QSM (blauw) en standaardmacrofaunameetnet (groen, cursief). 
Tabel 1: Meetpuntinformatie en bemonsterd habitat per locatie.

\begin{tabular}{|c|c|c|c|c|c|c|c|c|c|c|c|}
\hline \multirow[t]{2}{*}{ Code } & \multirow[t]{2}{*}{ Omschrijving } & \multicolumn{2}{|c|}{ Coordinaten } & \multirow{2}{*}{$\begin{array}{l}\text { KRW } \\
\text { type }\end{array}$} & \multirow[t]{2}{*}{ Datum } & \multicolumn{6}{|c|}{ Bemonsterd habitat (m geschept) } \\
\hline & & $\mathbf{x}$ & $\mathbf{y}$ & & & planten & slib & zand & takken & detritus & oever \\
\hline 252140 & Benedenstrooms Hugten & 174809.8 & 370585.8 & R4 & $27 / 3 / 2018$ & 0.25 & & 0.25 & & & \\
\hline 252142 & Waterberging Rummeling & 174166.4 & 370951.5 & R4 & $27 / 3 / 2018$ & 0.25 & & 0.25 & & & \\
\hline 252143 & Net bovenstrooms uitstroom Kamersvenloop & 173861.2 & 371084.1 & $\mathrm{R} 4$ & $27 / 3 / 2018$ & 0.15 & 0.25 & & 0.10 & & \\
\hline 252144 & Benedenstrooms uitstroom Kamersvenloop & 173665.3 & 371092.6 & R4 & $27 / 3 / 2018$ & 0.15 & & 0.10 & 0.10 & 0.15 & \\
\hline 252147 & Bovenstrooms uitstroom bos De Pan & 172936.7 & 371599.1 & $\mathrm{R} 4$ & $27 / 3 / 2018$ & 0.15 & & 0.25 & & 0.10 & \\
\hline 252148 & Bij De Stoeiing & 172454.3 & 371798.4 & R4 & $27 / 3 / 2018$ & 0.10 & & 0.10 & & 0.30 & \\
\hline 252149 & Bij Stoeiing, t.h.v. boerderij Stoeiing & 172180.2 & 371982.9 & $\mathrm{R} 4$ & $27 / 3 / 2018$ & & & 0.25 & & 0.25 & \\
\hline 252150 & Bovenstrooms monding Rakervenloop & 171607.4 & 372240.6 & $\mathrm{R} 4$ & $27 / 3 / 2018$ & 0.25 & & 0.10 & & 0.15 & \\
\hline 252151 & Benedenstrooms monding Rakerloop & 171467.3 & 372486.6 & $\mathrm{R} 4$ & $29 / 3 / 2018$ & & & 0.25 & & 0.10 & 0.15 \\
\hline 252156 & Bovenstrooms monding Sterkselsch kanaal & 169542.8 & 374082.9 & R4 & $29 / 3 / 2018$ & & & 0.25 & & 0.10 & 0.15 \\
\hline 252157 & Benedenstrooms instroom Peelvenloop & 169693.8 & 374947.0 & R5 & $29 / 3 / 2018$ & & & 0.25 & & 0.15 & 0.10 \\
\hline 252158 & Ter hoogte van Kempenhaeghe, Heeze & 169612.8 & 375324.8 & R5 & $29 / 3 / 2018$ & & & 0.25 & & 0.15 & 0.10 \\
\hline 252159 & Ter hoogte van Kapellerput & 169553.9 & 375678.7 & R5 & $29 / 3 / 2018$ & & & 0.25 & & 0.15 & 0.10 \\
\hline 252160 & Bovenstrooms Somerenseweg & 169579.3 & 376094.6 & R5 & $29 / 3 / 2018$ & & & 0.25 & & 0.15 & 0.15 \\
\hline 252161 & Tussen Boschlaan en Somerenseweg & 169360.1 & 376462.2 & R5 & $29 / 3 / 2018$ & & & 0.25 & & 0.15 & 0.10 \\
\hline 252162 & Nabij monding in de Kleine Dommel & 169140.4 & 376993.6 & R5 & 29/3/2018 & & & 0.25 & 0.05 & 0.15 & 0.05 \\
\hline
\end{tabular}


Voor iedere locatie is een aantal milieuparameters genoteerd en zijn metingen verricht aan het zuurstofgehalte, de watertemperatuur en de stroomsnelheid. De stroomsnelheid is gemeten met een Nautilus door bij de meetlocaties een raai te maken; deze meting is later dan de QSm bemonstering uitgevoerd (8 juni 2018). Op deze raai is op 3 plekken (rechts, midden, links) de stroomsnelheid gemeten en zijn de waarden vervolgens gemiddeld. Gezien de beperkte waterdiepte was het niet mogelijk om op verschillende dieptes te meten. De watertemperatuur en het zuurstofgehalte zijn eenmalig op alle punten gemeten ten tijde van de bemonstering. Een tweede meting van het zuurstofgehalte op 8 juni 2018 was niet op alle locaties gebruikt. Aangezien het patroon in deze dataset overeen kwam met dat van de eerdere meting is alleen de eerste set gebruikt in de analyse. Gezien de beperkte waterdiepte was het niet mogelijk om op verschillende dieptes te meten. De stroomsnelheid is wat later in het seizoen gemeten dan oorspronkelijk de bedoeling was. Hierdoor zal de stroomsnelheid ook iets lager zijn dan ten tijde van de monstername. Wel zie je goed verschillen tussen locaties. Overigens hebben we $2 x$ het zuurstofgehalte gemeten. Een keer bij de monstername en een keer bij de stroomsnelheidsmeting.

Een overzicht van de parameters wordt gegeven in tabel 2.

Tabel 2: Milieuparameters Sterkselsche Aa

\begin{tabular}{|l|l|l|}
\hline Categorie & Parameter & Waarden \\
\hline Dimensies & Watertype & R4, R5 \\
\hline & Breedte & $\mathrm{m}$ \\
\hline & Diepte & $\mathrm{m}$ \\
\hline Morfologie en landschap & Landschappelijke ligging & niet natuurlijk, half natuurlijk \\
\hline & Meandering & geen, matig \\
\hline & Oeverbegroeiing & geen, matig \\
\hline & Profiel & $\begin{array}{l}\text { Genormaliseerd, verwaarloosd } \\
\text { normprofiel }\end{array}$ \\
\hline Substraat & Beschaduwing & $\%$ \\
\hline & Substraatdifferentiatie & uniform, matig divers \\
\hline & Slib & $\%$ \\
\hline & Fijn organisch materiaal (FPOM) & $\%$ \\
\hline & Grof organisch materiaal (CPOM) & $\%$ \\
\hline & Hout & $\%$ \\
\hline & Waterplanten & $\%$ \\
\hline Fysisch-chemische variabelen & Leem & $\%$ \\
\hline & Zand & $\%$ \\
\hline & Zuurstofverzadiging & $\%$ \\
\hline Beheer en onderhoud & Stroomsnelheid & $\mathrm{m} / \mathrm{s}$ \\
\hline & Watertemperatuur & ${ }^{\circ} \mathrm{C}$ \\
\hline & Onderhoud & $\begin{array}{l}\text { schoning: volledig, gedeeltelijk, } \\
\text { geen }\end{array}$ \\
\hline
\end{tabular}

\subsection{Analyse}

Om inzicht te krijgen in de stressoren die spelen in de Sterkselsche Aa is er een koppeling gemaakt tussen de in de quickscan gevonden taxa en de milieu- en habitatpreferenties (Verberk et al. 2012) en de gevoeligheid voor toxische stoffen (SPEAR, Liess \& van der Ohe 2005) van deze taxa. Er is eerst een selectie gemaakt van preferentieklassen die in theorie inzicht zouden kunnen geven in de rol van bepaalde sleutelfactoren binnen het 
beekecosysteem, de zogenoemde indicatieve preferentieklassen (Tabel 3). Vervolgens is de gemiddelde preferentiescore van alle geclassificeerde taxa binnen de in de database opgenomen families of genera, in het geval van EPT taxa, berekend voor deze preferentieklassen. Daarna zijn alle taxa gescoord met een score $\geq 5$ in de indicatieve preferentieklassen. Dit zijn de indicatoren. De indicatoren zijn vervolgens geteld in de monsters genomen in de Sterkselsche Aa en gedeeld door het totaal aantal aangetroffen taxa in het monster (Tabel 3).

Om de gevonden scores te kunnen waarderen op een gradient van slecht naar goed, moeten deze geijkt worden op data van slechte en zeer goede locaties. Immers bestaat een levensgemeenschap nooit volledig uit taxa met één bepaalde preferentie. Om deze ijking te kunnen uitvoeren zijn de metrics berekend voor de dataset gebruikt om de Nederlandse bekentypologie op te stellen (Verdonschot \& Nijboer 2004). Binnen deze dataset zijn goede monsters geselecteerd op basis van hun toegekende kwaliteitsklasse (score 5) en de berekende $\mathrm{KRW}$-score $(\mathrm{EKR} \geq 0.8)$. Hetzelfde is gedaan voor de slechte monsters (kwaliteitsklasse 1, EKR $\leq 0.2$ ). Op basis van deze criteria zijn respectievelijk 23 en 12 monsters gebruikt om de ijkwaarden vast te stellen door de gemiddelde waarde te berekenen per preferentie (Tabel 3). Opgemerkt moet worden dat deze monsters geen QSM monsters zijn maar standaardnetmonsters, omdat er geen QSM monsters beschikbaar zijn van dit type locaties. De ijkwaarden geven direct het onderscheidend vermogen weer van de indicatieve preferentieklassen. Het blijkt dat sommige preferenties niet of amper onderscheidend zijn tussen goede en slechte locaties. Voor een goede beoordeling is een gradient oftewel voldoende spreiding tussen de laagste en hoogte waarde van groot belang. Uiteindelijk bleken vier preferenties indicatief: aandeel oligosaprobe taxa oftewel de mate van organische belasting van de beek, het aandeel stromingsminnende (rheofiele) taxa, wat het stromende karakter van de beek aangeeft met de bijbehorende omstandigheden (zuurstofgehalte, substraten), het aandeel stilstaand watertaxa, wat het 'moeraskarakter' van beken aangeeft met factoren als stagnatie, verslibbing, waterplanten. Tenslotte geeft het aandeel ongevoelige taxa de invloed van gewasbeschermingsmiddelen weer. De ijkwaarden zijn gebruikt om de gevonden waarden te schalen van 0 (slechtste score) tot 1 (beste score). De scores zijn per parameter op kaart weergegeven en vergeleken met de EKR scores van de standaardnetmonsters van de drie meetnetpunten in de Sterkselsche Aa. Daarnaast is een vergelijking gemaakt op basis van de indicatortaxa Noord Brabant (Verdonschot \& Verdonschot 2017), welke apart gescoord zijn tijdens de QSM.

Tabel 3: Metrics gebruikt voor de beoordeling van de QSM resultaten.

\begin{tabular}{|c|c|c|c|c|c|}
\hline \multirow[b]{2}{*}{ Parameter } & \multirow[b]{2}{*}{ Preferentieklasse } & \multirow[b]{2}{*}{ Sleutelfactor } & \multicolumn{2}{|c|}{$\begin{array}{l}\text { IJkwaarden } \\
\text { (aandeel taxa) }\end{array}$} & \multirow[t]{2}{*}{ Gebruikt } \\
\hline & & & $\begin{array}{l}\text { Beste } \\
\text { locaties } \\
\text { NL }\end{array}$ & $\begin{array}{l}\text { Slechtste } \\
\text { locaties } \\
\text { NL }\end{array}$ & \\
\hline Diepte & Ondiep (bron) & Temperatuur & 0.014 & 0.003 & $\mathrm{X}$ \\
\hline Droogval & Temporair (3 klassen) & Droogval & 0.013 & 0.056 & $\mathrm{X}$ \\
\hline \multirow[t]{2}{*}{ Saprobie } & Oligosaproob & Zuurstof/toxiciteit & 0.270 & 0.000 & V \\
\hline & $\begin{array}{l}\text { A- } \\
\text { mesosaproob+polysaproob }\end{array}$ & Zuurstof/toxiciteit & 0.071 & 0.059 & $\mathrm{X}$ \\
\hline \multirow[t]{2}{*}{ Stroming } & $\begin{array}{l}\text { Matig stromend + Snel } \\
\text { stromend }\end{array}$ & Stroming/zuurstof & 0.458 & 0.042 & $\mathrm{~V}$ \\
\hline & Stilstaand & Stagnatie/verslibbing & 0.098 & 0.405 & V \\
\hline Saliniteit & Niet zoet (4 klassen) & Saliniteit & 0.000 & 0.000 & $\mathrm{X}$ \\
\hline Zuurgraad & Zwak zuur + zuur & Zuurgraad & 0.050 & 0.051 & $\mathrm{X}$ \\
\hline Toxiciteit & Ongevoelig & Toxiciteit pesticiden & 0.374 & 0.742 & V \\
\hline
\end{tabular}

Om een beeld te krijgen van de relatie tussen de taxonsamenstelling en de milieugegevens van de Sterkselsche Aa is een multivariate analyse uitgevoerd in CANOCO for Windows 
5.10. Er is gebruik gemaakt van de detrended correspondence analysis (DCA) om de taxonsamenstelling van alle QSM monsterlocaties te analyseren. Om de patronen te kunnen interpreteren zijn de milieuvariabelen in de analyse meegenomen als supplementaire variabelen (indirecte analyse). Dit wil zeggen dat ze geen invloed uitoefenden op de ligging van van de monsterpunten in de ordinatie. Alle continue milieuvariabelen zijn loggetransformeerd voordat de analyse werd uitgevoerd. Taxa die weinig zijn gevonden kregen in de analyse een lager gewicht (downweighting of rare species) om te voorkomen dat een eenmalige waarnemingen (welke ook toeval zouden kunnen zijn) grote invloed konden uitoefenen op de analyse. 


\section{Resultaten}

\subsection{Taxonrijkdom op basis van de QSM}

In totaal zijn 61 taxa waargenomen op de 24 locaties (Tabel 4). Gemiddeld waren er 16 taxa in een monster aanwezig; het kleinste aantal taxa bedroeg 8, het grootste aantal 23 (Figuur 2).

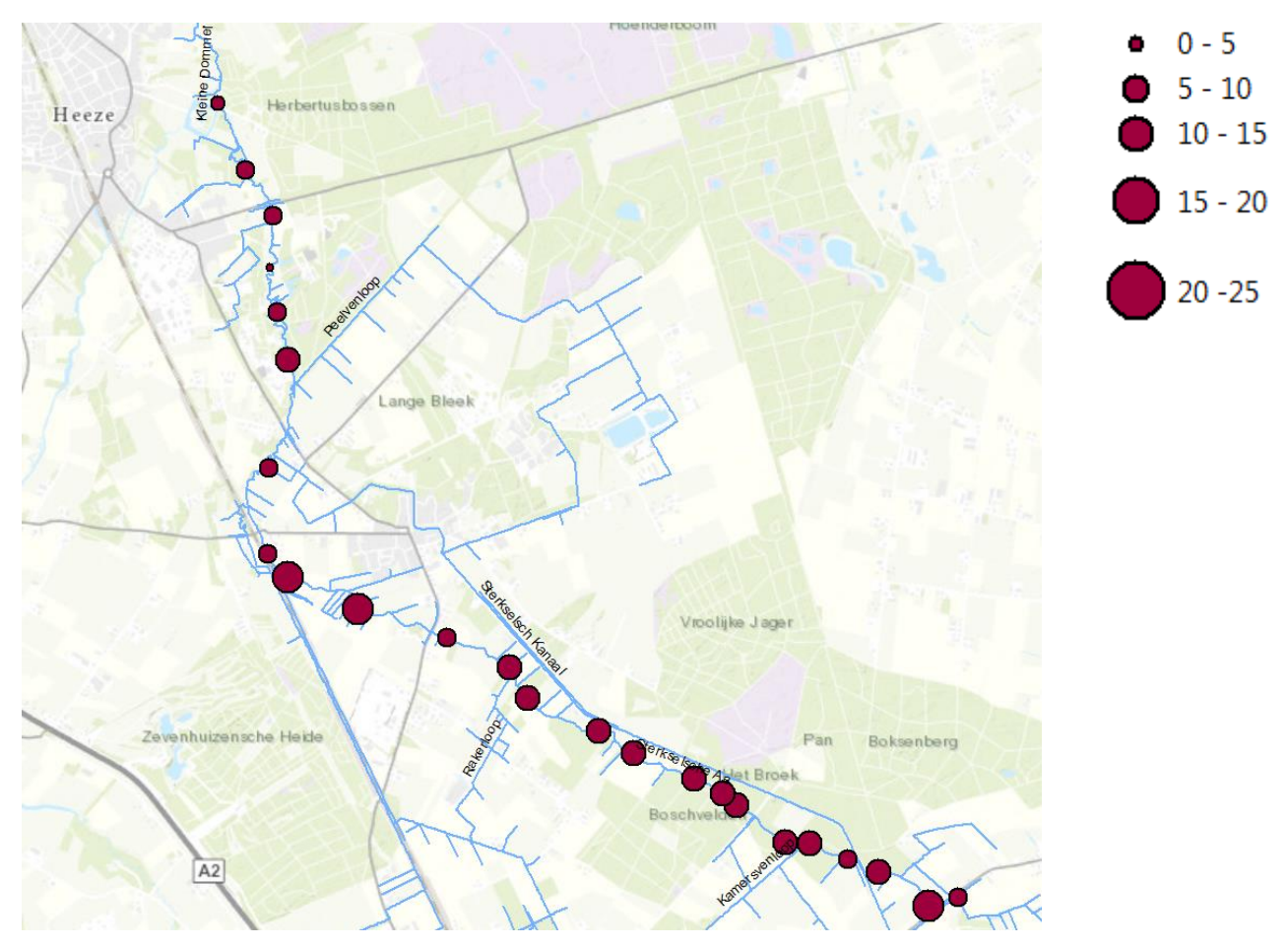

Figuur 2: Aantal waargenomen taxa in de QSM monsters per locatie.

\subsection{QSM preferentiescores}

Figuur 3 geeft per locatie de beoordeling op basis van de vier preferenties. Er is een duidelijke ruimtelijke verdeling van de scores te zien, waarbij de bovenloop relatief slecht scoort op stroming, stagnatie en toxiciteit en het meer benedenstrooms gelegen gedeelte relatief goed. Het aandeel stromingsminnende taxa (en met binding met daarbij voorkomende substraten en hoge zuurstofgehalten) scoort het beste (zeer goed) nabij de monding in de Kleine Dommel en goed ter hoogte van Kempenhaeghe bij Heeze. Het aandeel stilstaand-water taxa, indicatief voor o.a. stagnatie, waterplanten en organische substraten, laat een sterk heterogeen beeld zien, varierend van slecht tot zeer goed. Het aandeel voor gewasbeschermingsmiddelen gevoelige taxa (toxiciteit insecticiden op basis van SPEAR) scoort zeer goed ter hoogte van Boschveld De Pan en vanaf de instroom van de Peelvenloop, met uitzondering van het punt tussen de Boschlaan en Somerenseweg dat een terugval naar matig laat zien. Het aandeel taxa dat een hoge gevoeligheid heeft voor organische belasting scoort in zijn geheel relatief laag, met de hoogste scores (matig) op de locaties benedenstrooms de instroom van de Peelvenloop en ter hoogte van de Kapellerput. Het vrijwel ontbreken van deze gevoelige taxa geeft aan dat de organische belasting van het systeem aanzienlijk is. Wanneer de preferenties gemiddeld worden, kan een overall QSM beoordeling worden opgesteld, waarbij het benedenstroomse gedeelte van de Sterkselsche Aa over het algemeen goed scoort en het meest bovenstrooms gelegen gedeelte slecht (Figuur 4). 
Tabel 4: Waargenomen taxa QSM. De ligging van de locaties, aangegeven met locatiecodes, is weergegeven in tabel 1 en figuur 1.

\begin{tabular}{|c|c|c|c|c|c|c|c|c|c|c|c|c|c|c|c|c|c|c|c|c|c|c|c|c|c|}
\hline \multirow[t]{2}{*}{ Hoofdgroep } & \multirow[t]{2}{*}{ Taxon } & \multicolumn{24}{|c|}{ Locatiecode } \\
\hline & & 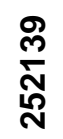 & $\begin{array}{l}\text { \& } \\
\text { స్ } \\
\text { }\end{array}$ & $\begin{array}{l}\overline{\text { ป }} \\
\text { స్ }\end{array}$ & $\begin{array}{l}\text { フ } \\
\text { స్ } \\
\text { న్ }\end{array}$ & 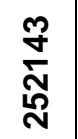 & $\begin{array}{l}\text { \& } \\
\text { స్ }\end{array}$ & $\frac{\text { \& }}{\underset{\text { స్ }}{\text { N }}}$ & $\begin{array}{l}\text { + } \\
\text { స్ } \\
\text { న్ }\end{array}$ & $\begin{array}{l}\frac{\text { J }}{\text { స్ }} \\
\text { }\end{array}$ & 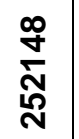 & $\begin{array}{l}\underset{+}{\mathbb{N}} \\
\text { న్ }\end{array}$ & 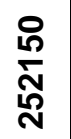 & $\frac{\overline{\text { నn }}}{\text { స్ }}$ & $\frac{\text { గิ }}{\text { ฟิ }}$ & $\begin{array}{l}\text { గొ } \\
\text { స్స్ } \\
\text { న్ }\end{array}$ & 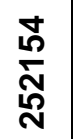 & $\begin{array}{l}\text { مٌ } \\
\text { స్ } \\
\text { స్ }\end{array}$ & $\begin{array}{l}\text { గొ } \\
\text { స్ } \\
\text { స్ }\end{array}$ & $\frac{\text { ñ }}{\text { స్ }}$ & 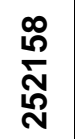 & $\begin{array}{l}\text { గొ } \\
\text { స్ } \\
\text { న్ }\end{array}$ & $\begin{array}{l}\text { ৫ } \\
\text { స్ }\end{array}$ & $\frac{\bar{\sigma}}{\text { స్ }}$ & ָั \\
\hline \multirow[t]{3}{*}{ Bloedzuigers } & Erpobdellidae & & & 1 & & 1 & & & & 1 & 1 & 1 & 1 & & & 1 & 1 & 1 & & & 1 & & & & \\
\hline & Glossiphoniidae & & 1 & & & & & 1 & 1 & & 1 & & 1 & & & & 1 & 1 & & & & & & & \\
\hline & Hirudinidae & 1 & & & & & & & & & & & 1 & & & & & & & & & & & & \\
\hline \multirow[t]{3}{*}{ Borstelwormen } & Lumbriculidae & 1 & 1 & & & & & & & & 1 & & 1 & 1 & 1 & 1 & 1 & & 1 & 1 & & & 1 & 1 & \\
\hline & Naididae & & 1 & 1 & 1 & 1 & & 1 & & & & & & & & 1 & 1 & & & 1 & & & & & \\
\hline & Tubificidae & 1 & 1 & 1 & 1 & 1 & 1 & 1 & 1 & 1 & 1 & 1 & 1 & 1 & 1 & 1 & 1 & 1 & 1 & 1 & 1 & 1 & 1 & 1 & 1 \\
\hline \multirow[t]{2}{*}{ Platwormen } & Dugesiidae & 1 & & & & & & & & & & & & & & & & & & & & & & & \\
\hline & Planariidae & & 1 & & & & 1 & & & & & & & & & & & & & & & & & & \\
\hline \multirow[t]{8}{*}{ Watermijten } & Arrenuridae & & & 1 & & & & & & & & & & & & & 1 & & & & & & & & \\
\hline & Hydrachnidae & & & & & 1 & 1 & 1 & 1 & 1 & 1 & 1 & 1 & 1 & & & 1 & & 1 & 1 & 1 & & 1 & 1 & 1 \\
\hline & Hygrobatidae & & & & & & & 1 & & & & & & & & & & & & 1 & & & & & \\
\hline & Lebertiidae & & & & & & & 1 & & & & & & & & & & & & 1 & & & 1 & & \\
\hline & Limnesiidae & & & & 1 & & & & & & & & & & & & & & & & & & & & \\
\hline & Mideopsidae & & & & & & 1 & & 1 & 1 & 1 & & & & & & & & 1 & & & & & & \\
\hline & Pionidae & & & & & & & & & & & & & & & & & & & & & & 1 & & \\
\hline & Unionicolidae & & & & & & & 1 & & & & & & & & & & & & & & & & & \\
\hline \multirow[t]{2}{*}{ Vlokreeften } & Crangonyctidae & & & & & & & & & & & & & 1 & 1 & & & & & & & & & & \\
\hline & Gammaridae & 1 & 1 & 1 & & 1 & & 1 & 1 & 1 & 1 & 1 & 1 & 1 & 1 & & 1 & 1 & 1 & 1 & 1 & & & 1 & 1 \\
\hline Waterpissebedden & Asellidae & 1 & 1 & 1 & 1 & 1 & 1 & 1 & 1 & 1 & 1 & & 1 & 1 & 1 & 1 & 1 & 1 & 1 & 1 & & 1 & 1 & 1 & \\
\hline \multirow[t]{5}{*}{$\begin{array}{l}\text { Muggen en } \\
\text { vliegen }\end{array}$} & Chironomidae & 1 & 1 & 1 & 1 & 1 & 1 & 1 & 1 & 1 & 1 & 1 & 1 & 1 & 1 & 1 & 1 & 1 & 1 & 1 & 1 & 1 & 1 & 1 & 1 \\
\hline & Ceratopogonidae & & 1 & & & & 1 & 1 & 1 & 1 & 1 & 1 & 1 & 1 & & 1 & & 1 & 1 & 1 & 1 & & 1 & & \\
\hline & Limoniidae & & & & & & & & & & & & & & & & & & & & 1 & & & & \\
\hline & Pediciidae & & & & & & & & & & & & & & & & & & & 1 & & & & & \\
\hline & Tabanidae & & & & & & & & 1 & & & 1 & 1 & 1 & & & & & & & 1 & 1 & & & \\
\hline
\end{tabular}




\begin{tabular}{|c|c|c|c|c|c|c|c|c|c|c|c|c|c|c|c|c|c|c|c|c|c|c|c|c|c|}
\hline \multirow[t]{2}{*}{ Hoofdgroep } & \multirow[t]{2}{*}{ Taxon } & \multicolumn{24}{|c|}{ Locatiecode } \\
\hline & & 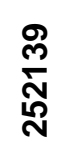 & $\begin{array}{l}\text { O } \\
\text { N } \\
\text { N }\end{array}$ & 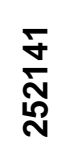 & $\underset{\text { ָั }}{\stackrel{N}{N}}$ & 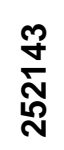 & 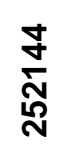 & $\underset{\text { N }}{\stackrel{\text { N }}{\mathbf{N}}}$ & $\begin{array}{l}\stackrel{0}{+} \\
\text { స్ } \\
\text { ฟै }\end{array}$ & 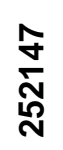 & $\underset{\text { స్ }}{\stackrel{\infty}{+}}$ & $\begin{array}{l}\underset{+}{\text { ฟ }} \\
\text { ฟ్ }\end{array}$ & $\begin{array}{l}\text { 유 } \\
\text { స్ } \\
\text { స్ }\end{array}$ & 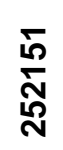 & $\begin{array}{l}\text { N } \\
\text { Ñ } \\
\text { N }\end{array}$ & 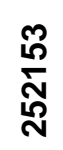 & 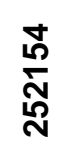 & $\stackrel{n}{\text { ก }}$ & 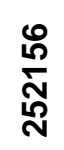 & $\underset{\text { N }}{\stackrel{N}{N}}$ & 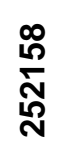 & 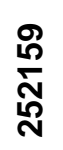 & $\begin{array}{l}\stackrel{0}{N} \\
\text { Nิ }\end{array}$ & 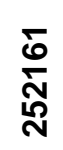 & 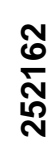 \\
\hline & Tipulidae & & & & & & & & & & & 1 & & & & & & & & & & & & & \\
\hline \multirow[t]{5}{*}{ Waterkevers } & Dytiscidae & & 1 & 1 & 1 & 1 & 1 & 1 & & 1 & & & & 1 & 1 & 1 & 1 & & & & & & & & \\
\hline & Gyrinidae & & & & & 1 & & 1 & & & & & & & & & & & & & 1 & & & & \\
\hline & Haliplidae & & 1 & & & & & & & 1 & & 1 & 1 & & & 1 & 1 & & & & & & & & \\
\hline & Hydrophilidae & & & & & & & & & 1 & & & & & & & & & 1 & & & & & & \\
\hline & Hydraenidae & & & & & & 1 & & & & & & & & & & & & & & & & & & \\
\hline \multirow[t]{4}{*}{ Waterwantsen } & Corixidae & & 1 & & & & & & & & & & & 1 & & 1 & 1 & & & 1 & 1 & & & & \\
\hline & Gerridae & & & & & & & & & & & & & & & & & & & & & & & 1 & \\
\hline & Notonectidae & & 1 & & & & & & & & & & & & & & & & & & & & & & \\
\hline & Pleidae & & 1 & & & & & & & & & & & & & & & & & & & & & & \\
\hline \multirow[t]{3}{*}{ Libellen en juffers } & Calopterygidae & & & & & & & & & & & & & & & 1 & & 1 & & & & & & & 1 \\
\hline & Coenagrionidae & 1 & 1 & & & & & & & & & & & & & 1 & 1 & 1 & & & & & & & \\
\hline & Platycnemididae & & & & & & & & & & & & & & & & & & & & & & & 1 & \\
\hline Slijkvliegen & Sialidae & & & & & 1 & 1 & & 1 & 1 & & 1 & & 1 & & & & 1 & & & & & & & \\
\hline Tweekleppigen & Sphaeriidae & 1 & 1 & 1 & 1 & 1 & 1 & 1 & 1 & 1 & 1 & 1 & 1 & 1 & 1 & 1 & 1 & 1 & & & & & & & \\
\hline \multirow[t]{8}{*}{ Slakken } & Ancylidae & & & & & & & & & & & & & & & & & & & & 1 & & & & \\
\hline & Bithyniidae & & 1 & & 1 & 1 & & & & & & & & & & & & & & & & & & & \\
\hline & Hydrobiidae & & & 1 & 1 & & & & 1 & 1 & & 1 & & 1 & & & & & & & & & & & \\
\hline & Lymnaeidae & & 1 & 1 & 1 & & 1 & & & & & 1 & 1 & & 1 & 1 & 1 & & & & & & & 1 & \\
\hline & Physidae & & & 1 & & & & & & & & & & & 1 & & & & & & & & & & \\
\hline & Planorbidae & & 1 & 1 & 1 & 1 & 1 & 1 & 1 & & 1 & 1 & 1 & 1 & 1 & 1 & 1 & 1 & & & & & & & \\
\hline & Valvatidae & 1 & 1 & 1 & 1 & 1 & & & & & & & 1 & 1 & 1 & 1 & & & & & & & & & \\
\hline & Viviparidae & 1 & & & & & 1 & & & & & & & & & & & & & & & & & & \\
\hline \multirow[t]{3}{*}{ Haften } & Caenidae & & & & & & & & & & & & & & & & & & & & & 1 & & & \\
\hline & Baetis & & & & & & & & & & & & & & & & & & & 1 & & & & & \\
\hline & Cloeon & 1 & 1 & 1 & 1 & & & & & & & & & & & & 1 & & & & & & & & 1 \\
\hline
\end{tabular}




\begin{tabular}{|c|c|c|c|c|c|c|c|c|c|c|c|c|c|c|c|c|c|c|c|c|c|c|c|c|c|}
\hline \multirow[t]{2}{*}{ Hoofdgroep } & \multirow[t]{2}{*}{ Taxon } & \multicolumn{24}{|c|}{ Locatiecode } \\
\hline & & 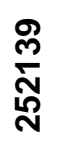 & $\begin{array}{l}\text { ণ্ণ } \\
\text { ণิ } \\
\text { ָे }\end{array}$ & $\begin{array}{l}\bar{\Xi} \\
\frac{\sigma}{N} \\
\text { ஸิ }\end{array}$ & $\begin{array}{l}\text { Y } \\
\stackrel{\sim}{N} \\
\text { ָ̊ }\end{array}$ & $\begin{array}{l}\stackrel{m}{+} \\
\stackrel{\sim}{N} \\
\stackrel{\sim}{N}\end{array}$ & $\begin{array}{l}\text { J } \\
\text { స̃ } \\
\text { ஸे }\end{array}$ & 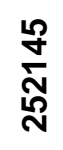 & 守 & $\begin{array}{l}\underset{\sim}{\sim} \\
\text { N } \\
\text { N }\end{array}$ & $\begin{array}{l}\stackrel{\infty}{+} \\
\stackrel{\sim}{N} \\
\text { న }\end{array}$ & $\begin{array}{l}\underset{+}{+} \\
\text { ָิ } \\
\text { ஸे }\end{array}$ & 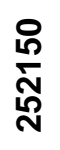 & $\begin{array}{l}\frac{\pi}{n} \\
\text { กิ } \\
\text { N }\end{array}$ & $\begin{array}{l}\text { N } \\
\text { ָั } \\
\text { ஸे }\end{array}$ & $\begin{array}{l}\text { న్ } \\
\frac{\text { N }}{\text { N }} \\
\text { }\end{array}$ & 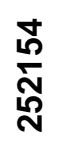 & $\begin{array}{l}\text { م } \\
\frac{\text { N }}{\text { Nิ }} \\
\text { }\end{array}$ & $\begin{array}{l}0 \\
\frac{0}{N} \\
\stackrel{م}{N}\end{array}$ & 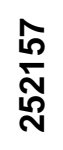 & 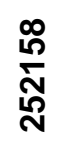 & 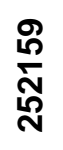 & $\begin{array}{l}\frac{0}{N} \\
\text { N } \\
\text { N }\end{array}$ & $\begin{array}{l}\bar{\emptyset} \\
\underset{\sim}{N} \\
\text { N }\end{array}$ & 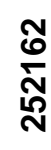 \\
\hline Steenvliegen & Nemoura & & & & & 1 & 1 & 1 & 1 & 1 & 1 & 1 & & & 1 & 1 & 1 & & & 1 & 1 & 1 & 1 & 1 & 1 \\
\hline \multirow[t]{10}{*}{ Kokerjuffers } & Leptoceridae & & & & & & & & & & 1 & & & & & & & & & & & & & & \\
\hline & Beraeodes & & & & & & & & 1 & & 1 & & & & & & & & & & & & & & \\
\hline & Hydropsyche & & & & & & & & & & & & & & & & & & & & & & & & 1 \\
\hline & Athripsodes & & & & & & & & & & & & & & 1 & 1 & 1 & & & & & & & & \\
\hline & Mystacides & & & & & & & & & & & 1 & 1 & & & 1 & & & & 1 & & & & 1 & \\
\hline & Anabolia & & & 1 & & & & 1 & 1 & 1 & 1 & & 1 & & & & 1 & 1 & 1 & 1 & & 1 & & 1 & 1 \\
\hline & Glyphotaelius & & & & & 1 & 1 & & & & & & & & & 1 & & & & & & & & & \\
\hline & Halesus & & & & & & & & & & & & & & & & & & & 1 & 1 & & 1 & & 1 \\
\hline & Limnephilus & 1 & 1 & 1 & & 1 & 1 & 1 & & 1 & 1 & 1 & 1 & 1 & 1 & 1 & 1 & 1 & 1 & 1 & 1 & 1 & 1 & 1 & \\
\hline & Molanna & & & & & & 1 & & & & & & & & & & 1 & 1 & & & & & & & \\
\hline
\end{tabular}

Tabel 5: Vergelijking tussen de QSM preferentiescores, inclusief het gemiddelde van de preferentiescores, en de EKR voor de desbetreffende standaardnetmonsters op overlappende locaties. KRW beoordeling voor R4 is opgedeeld in R4oud, de originele maatlat en de nieuwe R4 maatlatten met de subtypen R4a (laag verhang bovenloop) en R4b (bovenloop met meer verhang).

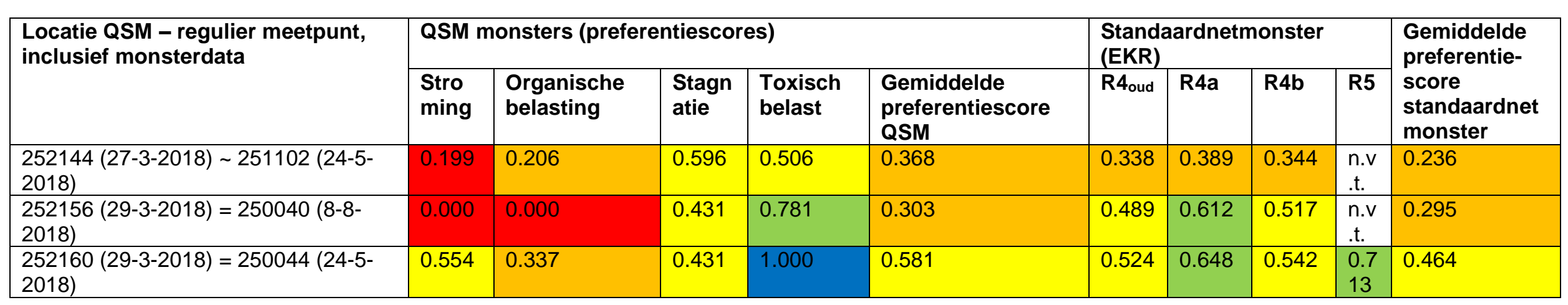



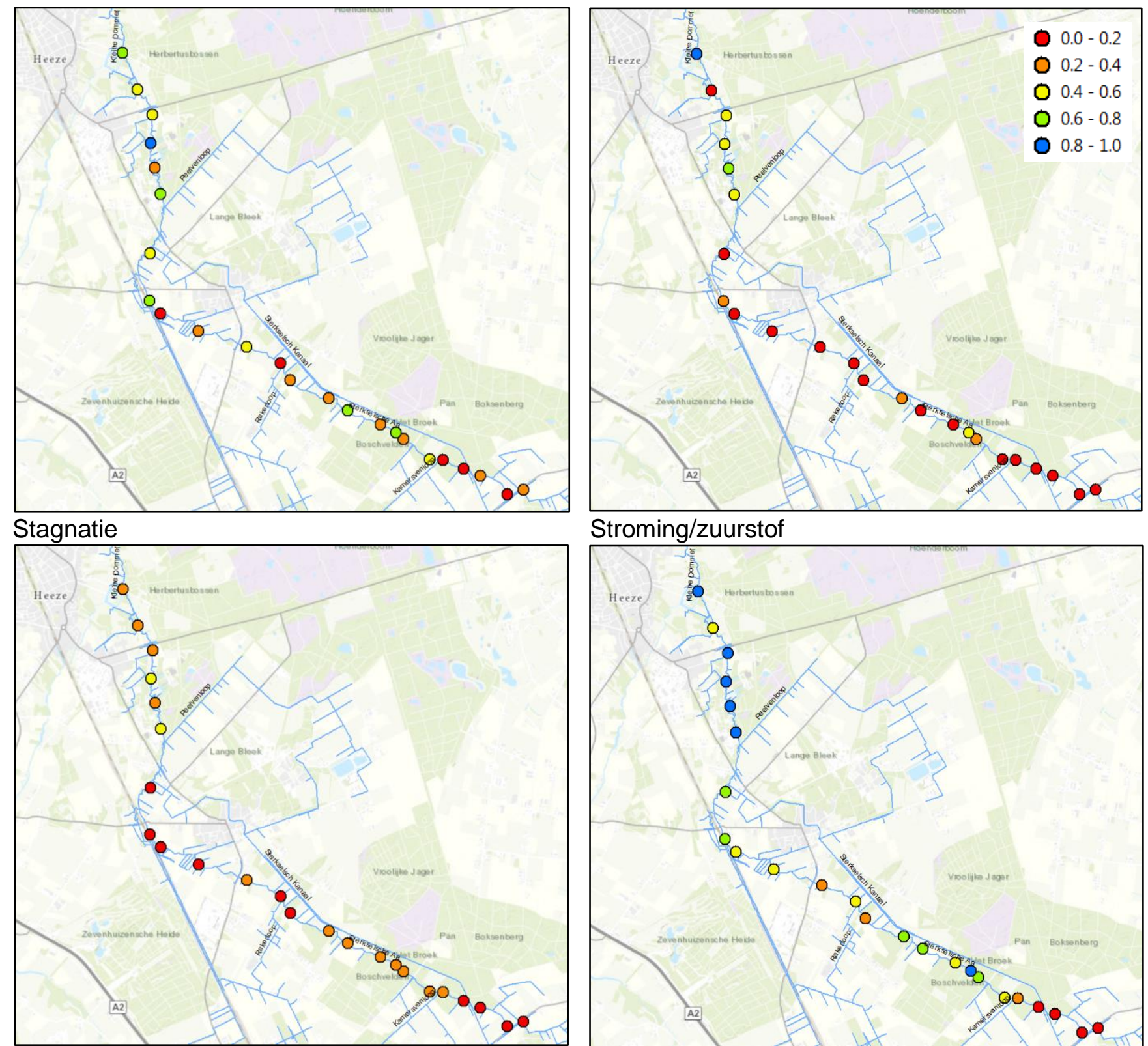

Organische belasting

Stroming/zuurstof

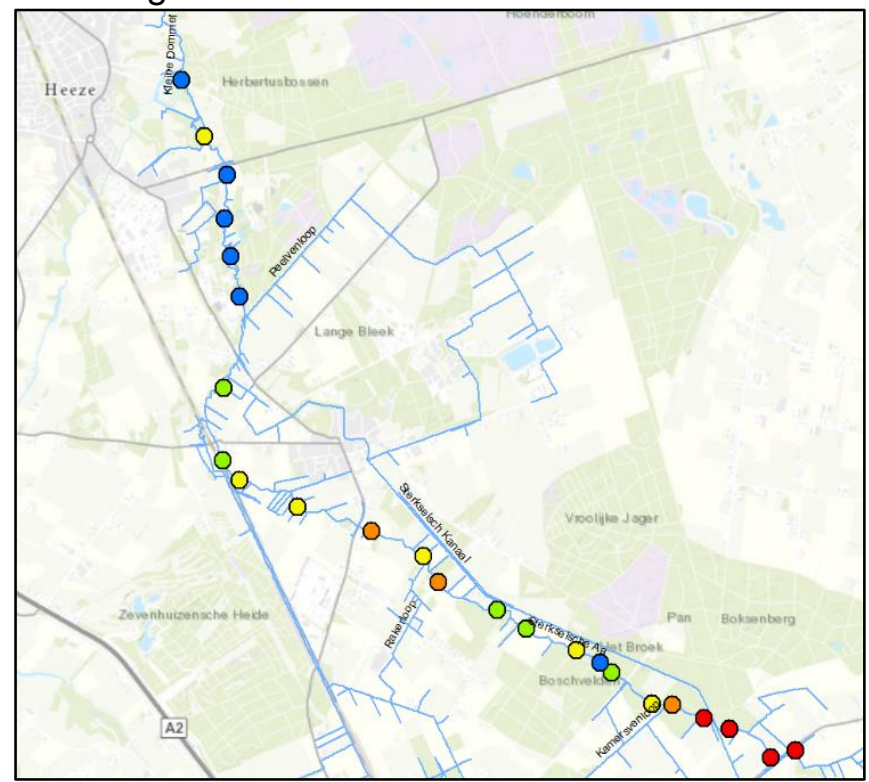

Toxiciteit

Figuur 3: QSM beoordeling locaties Sterkselsche Aa per preferentie. De kwaliteit, uitgedrukt in een schaal van 0 tot 1 , is weergegeven met verschillende kleuren. 


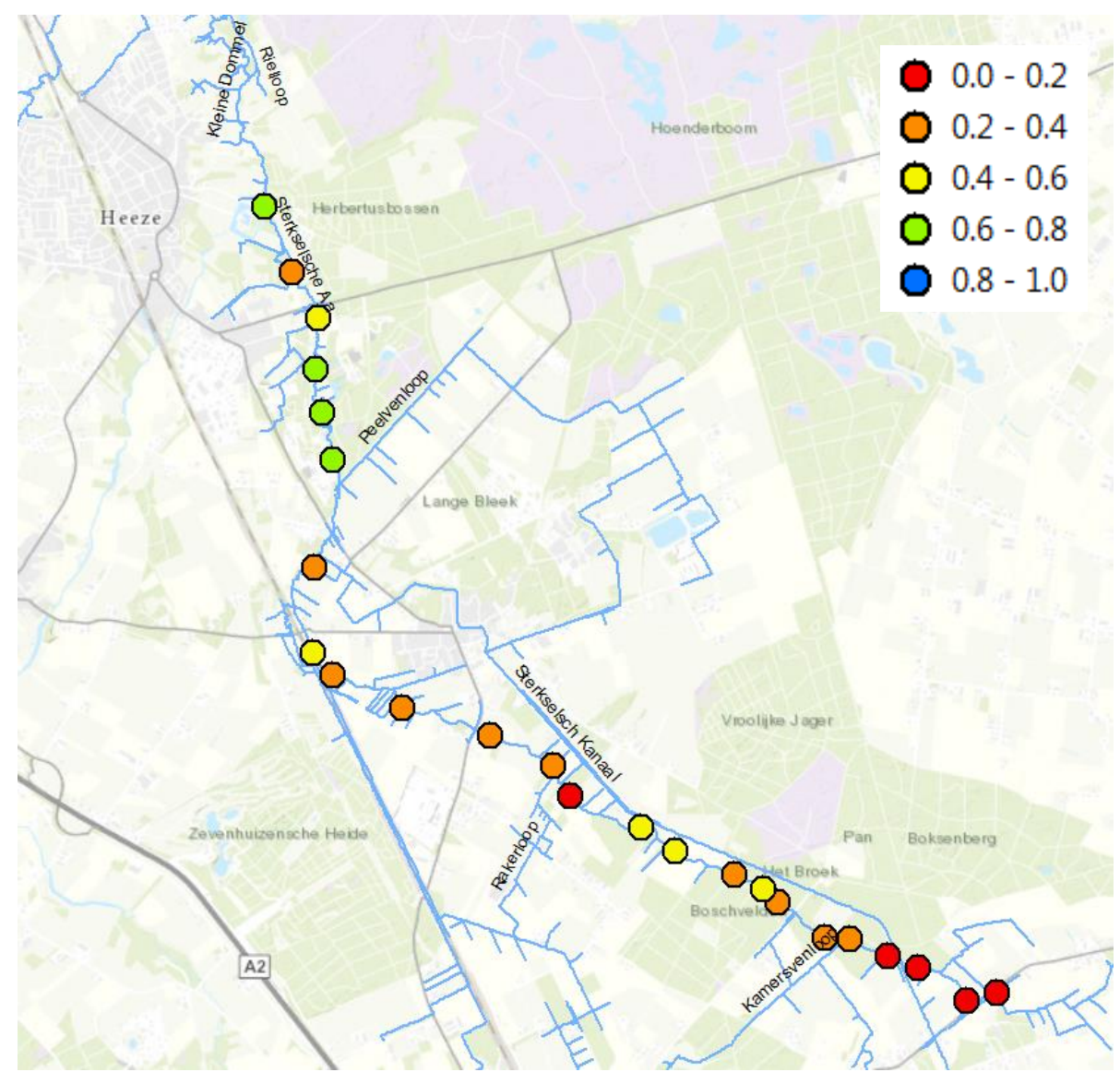

Figuur 4: QSM beoordeling locaties Sterkselsche Aa op basis van het gemiddelde van de vier preferenties: stroming, stagnatie, organische belasting en toxiciteit. De kwaliteit, uitgedrukt in een schaal van 0 tot 1 , is weergegeven met verschillende kleuren.

\subsection{Vegelijking QSM preferentiescores en EKR KRW maatlatten}

Voor de drie reguliere meetpunten is een vergelijking gemaakt met de dichtstbijzijnde QSM meetpunten tussen de EKR-scores en de preferentiescores (Tabel 5). De data waarop de monsters genomen zijn, kwamen niet overeen. De locaties bovenstrooms de monding van het Sterkselsch kanaal zijn getypeerd als R4 en de locaties benedenstrooms als R5. Omdat het deel benedenstrooms het kanaal onderdeel is van het waterlichaam Kleine Dommel is ervoor gekozen om dit deel van de Aa inclusief Kleine Dommel als R5 te typeren. Er is echter in het veld geen sprake van zo'n scherpe overgang. Daarom is naast de R5 maatlat voor de meest benedenstroomse punten voor alle punten de maatlat voor R4 berekend, zowel de originele R4-maatlat als de nieuwe R4-subtypen-maatlatten. Voor het meest bovenstroomse punt komt de beoordeling van de QSM preferentiescores en de EKR overeen, beide scoren ontoereikend. Het tweede punt wordt door de QSM slechter beoordeeld dan op basis van de EKR: ontoereikend versus matig-goed. Dit verschil wordt veroorzaakt door de preferentiescores voor stroming en organische belasting, die beide zeer slecht scoren op dit punt. Er is overigens wel een groot verschil in bemonsteringsdata voor deze punten, namelijk maart versus augustus. Wat hierbij mee kan spelen is dat in augustus de afvoer zeer laag was als gevolg van de droogte. Het meest benedenstroomse punt scoort het hoogst in zowel de QSM als op basis van de EKR, al ligt de beoordeling op basis van de QSM een klasse lager dan die van de KRW-maatlat: matig versus goed. Wanneer op basis van de standaardnetmonsters de gemiddelde preferentiescore wordt uitgerekend aan de hand van dezelfde methode als voor de QSM monsters wordt gehanteerd, dan komt er een vergelijkbaar patroon uit (Tabel 5). 


\subsection{Vegelijking QSM beoordeling en de indicatortaxa Noord Brabant}

De watermijt Mideopsis crassipes en de kokerjuffer Halesus radiatus zijn aangetroffen in de Sterkselsche Aa (Tabel 6). Vooral Halesus radiatus had een duidelijke binding met de hogere QSM preferentiescores en lijkt hiermee een goede indicator van kwalitatief betere locaties te zijn.

Tabel 6: Voorkomen indicatortaxa macrofauna laaglandbeken Noord-Brabant MC: Mideopsis crassipes en HR: Halesus radiatus op de QSM locaties met gemiddelde QSM-

preferentiescore.

\begin{tabular}{|l|l|l|l|}
\hline \multirow{2}{*}{ Locatie } & \multicolumn{2}{|l|}{ Aanwezigheid } & gem. \\
& QSM & HR & QS \\
\hline 252140 & & & 0.009828 \\
\hline 252142 & & & 0.016783 \\
\hline 252139 & & & 0.112965 \\
\hline 252141 & & & 0.114783 \\
\hline 252150 & & & 0.153797 \\
\hline 252143 & & & 0.206649 \\
\hline 252151 & & & 0.232140 \\
\hline 252154 & & & 0.237147 \\
\hline 252152 & & & 0.240101 \\
\hline 252153 & & & 0.250148 \\
\hline 252156 & 1 & & 0.303023 \\
\hline 252147 & 1 & & 0.334476 \\
\hline 252145 & & & 0.349034 \\
\hline 252144 & 1 & & 0.368242 \\
\hline 252161 & & & 0.372121 \\
\hline 252155 & & & 0.408665 \\
\hline 252149 & & & 0.409859 \\
\hline 252148 & 1 & & 0.470180 \\
\hline 252146 & 1 & & 0.566750 \\
\hline 252160 & & 1 & 0.580602 \\
\hline 252158 & & 1 & 0.602795 \\
\hline 252157 & & 1 & 0.688644 \\
\hline 252159 & & & 0.717964 \\
\hline 252162 & & 1 & 0.724786 \\
\hline & & & \\
\hline
\end{tabular}

\subsection{Multivariate analyse QSM monsters en milieuvariabelen}

Wanneer er een Detrended Correspondence analysis (PCA) met alle milieuvariabelen wordt uitgevoerd dan komt er een duidelijk patroon naar voren van met elkaar samenhangende milieuvariabelen (Tabel 7, Figuur 6). Het grootste gedeelte van de variatie in de dataset wordt verklaard langs de eerste ordinatie-as, welke een duidelijke opdeling laat zien (Figuur 6). Links in het diagram liggen de niet natuurlijke, genormaliseerde, waterplanten en fijnorganisch materiaal gedomineerde, volledig onderhouden trajecten. Deze scoren relatief laag op basis van de gemiddelde QSM preferenties. Rechts in het diagram, met de betere gemiddelde QSM preferentiescores, liggen de halfnatuurlijke, meer beschaduwde, niet onderhouden trajecten met een hogere stroomsnelheid en zuurstofverzadingspercentage. $\mathrm{Er}$ speelt hier overigens ook een dimensie of watertype-verschil doorheen, namelijk dat hier tegelijktijd ook de R5 monsterpunten liggen. 
Tabel 7: Milieuvariabelen QSM monsterpunten opgenomen ten tijde van de bemonstering. Afkortingen en coderingen: Landschappelijke ligging: 0: niet natuur, 1: half natuur; Meandering: 0: geen, 1: matig; Oeverbegroeiing: 0: geen, 1: matig; Profiel: 0: genormaliseerd, 1: verwaarloosd normprofiel; Substraatdifferentiatie: 0: geen, 1: matig; Onderhoud: 0: geen, 1: deels (bijv. bepaald \% bodem, talud eenzijdig), 2: volledig; FPOM fijn organisch materiaan; CPOM: grof organisch materiaal.

\begin{tabular}{|c|c|c|c|c|c|c|c|c|c|c|c|c|c|c|c|c|c|c|c|c|c|c|c|c|}
\hline \multirow[b]{2}{*}{ Variabele } & \multicolumn{24}{|c|}{ QSM monsterpunt } \\
\hline & 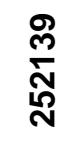 & $\begin{array}{l}\text { 워 } \\
\text { స్ }\end{array}$ & $\begin{array}{l}\overline{+} \\
\text { స్ } \\
\text { }\end{array}$ & $\begin{array}{l}\text { ホั } \\
\text { స్ } \\
\text { }\end{array}$ & 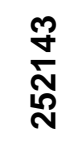 & 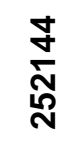 & 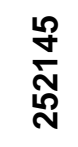 & 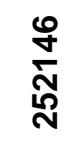 & $\begin{array}{l}\text { 志 } \\
\text { స్ }\end{array}$ & 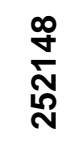 & $\begin{array}{l}\text { ホ } \\
\text { స్ } \\
\text { న్ }\end{array}$ & $\begin{array}{l}\text { 足 } \\
\text { స్ } \\
\text { N }\end{array}$ & 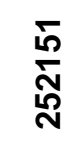 & $\begin{array}{l}\text { గ్ } \\
\text { స్ } \\
\text { }\end{array}$ & $\begin{array}{l}\text { గొ } \\
\text { त్ } \\
\text { N్}\end{array}$ & $\begin{array}{l}\text { ్ָ } \\
\text { స్ } \\
\text { N }\end{array}$ & $\begin{array}{l}\text { గొ } \\
\text { స్ } \\
\text { స్ }\end{array}$ & $\begin{array}{l}\text { ڤ్ } \\
\text { స్్ } \\
\text { స్ }\end{array}$ & 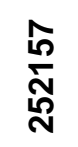 & 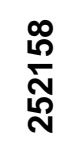 & 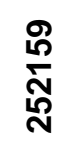 & 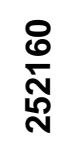 & $\begin{array}{l}\bar{\sigma} \\
\text { స్ } \\
\text { N }\end{array}$ & $\begin{array}{l}\text { ণ } \\
\text { స్ } \\
\text { N }\end{array}$ \\
\hline Breedte $(\mathrm{m})$ & 1.5 & 1 & 1.5 & 2 & 2.5 & 3 & 3 & 3 & 3 & 3 & 3.5 & 3 & 4 & 4 & 5 & 4.5 & 4.5 & 4.5 & 5 & 5 & 6 & 5 & 6 & 8 \\
\hline Diepte $(\mathrm{m})$ & 0.5 & 0.2 & 0.5 & 0.5 & 0.5 & 0.3 & 0.3 & 0.2 & 0.2 & 0.3 & 0.2 & 0.3 & 0.5 & 0.3 & 0.4 & 0.7 & 0.8 & 0.7 & 0.7 & 0.7 & 1.2 & 1.2 & 1 & 1.2 \\
\hline $\begin{array}{l}\text { Landschappelijke } \\
\text { ligging }\end{array}$ & 0 & 0 & 0 & 1 & 1 & 1 & 1 & 1 & 1 & 0 & 1 & 0 & 0 & 0 & 0 & 0 & 0 & 0 & 1 & 1 & 1 & 1 & 1 & 1 \\
\hline Meandering & 0 & 0 & 0 & 1 & 1 & 1 & 1 & 1 & 1 & 1 & 1 & 0 & 0 & 1 & 1 & 0 & 0 & 1 & 1 & 1 & 1 & 1 & 1 & 1 \\
\hline Oeverbegroeiing & 0 & 0 & 0 & 1 & 1 & 1 & 1 & 1 & 1 & 1 & 0 & 0 & 0 & 0 & 0 & 0 & 1 & 0 & 1 & 1 & 1 & 1 & 1 & 1 \\
\hline Profiel & 0 & 0 & 0 & 1 & 1 & 1 & 1 & 1 & 1 & 1 & 1 & 1 & 0 & 0 & 1 & 1 & 0 & 1 & 1 & 1 & 1 & 1 & 1 & 1 \\
\hline $\begin{array}{l}\text { Substraat } \\
\text { differentiatie }\end{array}$ & 0 & 0 & 0 & 0 & 1 & 1 & 0 & 0 & 0 & 0 & 0 & 0 & 0 & 0 & 0 & 0 & 0 & 0 & 0 & 0 & 0 & 0 & 0 & 0 \\
\hline FPOM (\%) & 0 & 0 & 0 & 0 & 0 & 20 & 20 & 10 & 0 & 0 & 20 & 10 & 30 & 20 & 10 & 20 & 10 & 20 & 20 & 10 & 10 & 5 & 10 & 10 \\
\hline CPOM (\%) & 0 & 0 & 0 & 0 & 0 & 10 & 30 & 30 & 10 & 10 & 10 & 20 & 10 & 10 & 30 & 10 & 20 & 5 & 10 & 10 & 20 & 15 & 20 & 20 \\
\hline Hout (\%) & 0 & 0 & 0 & 0 & 10 & 10 & 10 & 0 & 0 & 0 & 0 & 0 & 0 & 0 & 0 & 0 & 0 & 0 & 0 & 0 & 0 & 0 & 0 & 0 \\
\hline Leem (\%) & 0 & 0 & 10 & 0 & 0 & 0 & 0 & 0 & 0 & 0 & 0 & 0 & 0 & 0 & 0 & 0 & 0 & 0 & 0 & 0 & 0 & 0 & 0 & 0 \\
\hline Slib (\%) & 80 & 25 & 30 & 20 & 70 & 40 & 10 & 10 & 20 & 30 & 0 & 30 & 10 & 10 & 0 & 0 & 10 & 5 & 0 & 10 & 0 & 0 & 0 & 0 \\
\hline Waterplanten (\%) & 10 & 50 & 40 & 40 & 10 & 10 & 0 & 0 & 10 & 10 & 0 & 0 & 0 & 0 & 0 & 0 & 0 & 0 & 0 & 0 & 0 & 0 & 0 & 0 \\
\hline Zand (\%) & 10 & 25 & 20 & 30 & 10 & 10 & 30 & 50 & 60 & 40 & 70 & 40 & 50 & 60 & 60 & 70 & 60 & 70 & 70 & 70 & 70 & 80 & 70 & 70 \\
\hline $\begin{array}{l}\text { Zuurstofverzadigi } \\
\mathrm{n}(\%)\end{array}$ & 64 & 63 & 57 & 63 & 65 & 66 & 80 & 87 & 92 & 91 & 90 & 98 & 70 & 72 & 75 & 82 & 85 & 88 & 97 & 98 & 97 & 98 & 97 & 96 \\
\hline $\begin{array}{l}\text { stroomsnelheid } \\
(\mathrm{cm} / \mathrm{s})\end{array}$ & 9 & 12 & 6 & 7 & 8 & 7 & 11 & 15 & 11 & 11 & 13 & 9 & 9 & 12 & 10 & 7 & 9 & 14 & 16 & 19 & 17 & 14 & 18 & 16 \\
\hline $\begin{array}{l}\text { watertemperatuur } \\
\left({ }^{\circ} \mathrm{C}\right)\end{array}$ & 5.8 & 5.8 & 5.5 & 5.6 & 6 & 6.7 & 6.6 & 6.9 & 7.2 & 7.6 & 7.6 & 7.9 & 7.1 & 7.2 & 7.9 & 8.7 & 9.2 & 9.4 & 8.7 & 9.1 & 9.3 & 9.5 & 9.8 & 9.4 \\
\hline $\begin{array}{l}\text { Beschaduwing } \\
\text { (\%) }\end{array}$ & 0 & 0 & 50 & 50 & 80 & 80 & 80 & 80 & 80 & 0 & 50 & 0 & 0 & 0 & 20 & 0 & 0 & 50 & $\begin{array}{l}10 \\
0\end{array}$ & 50 & 80 & 80 & $\begin{array}{l}10 \\
0\end{array}$ & $\begin{array}{l}10 \\
0\end{array}$ \\
\hline Onderhoud & 2 & 2 & 2 & 1 & 1 & 1 & 1 & 1 & 1 & 1 & 1 & 1 & 1 & 1 & 1 & 1 & 1 & 1 & 0 & 0 & 1 & 1 & 0 & 0 \\
\hline
\end{tabular}



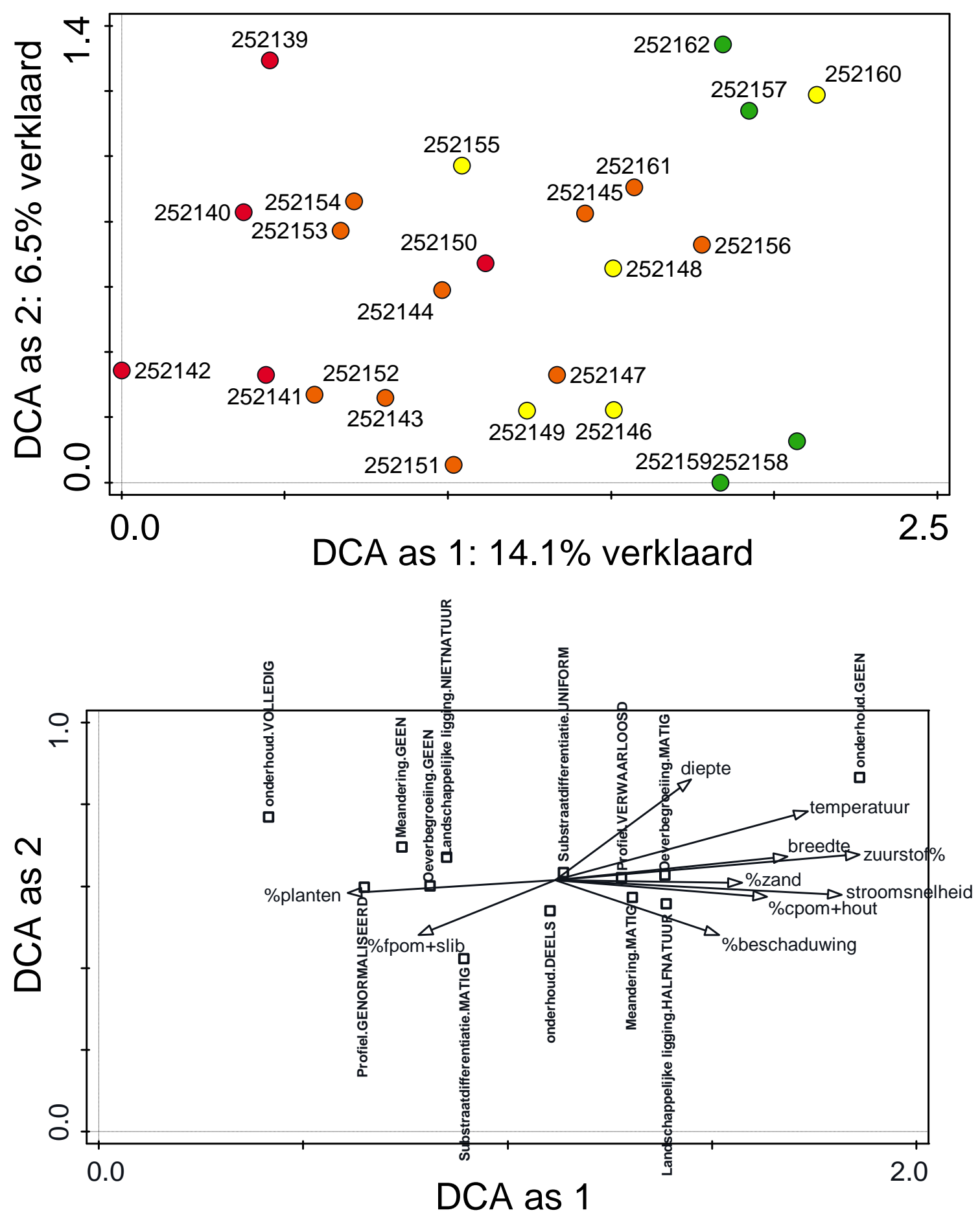

Figuur 5: Detrended correspondence analysis (DCA) ordinatie-as 1 en as 2 op basis van de taxonsamenstelling van de QSM monsterpunten (boven, zeldzame taxa gewogen) met hierin aangegeven de gemiddelde QSM preferentiescore. De bijbehorende supplementaire milieuvariabelen (onder) zijn aangeven met pijlen voor continue variabelen, zoals substraatbedekking en stroomsnelheid, waarbij de richting van de pijl een toename van de variabele op de monsterpunten corresponderend met een verandering in taxonsamenstelling laat zien. Nominale variabelen (klassen, zoals onderhoud of landschappelijke ligging) zijn aangegeven met vierkantjes, waarbij de ligging het zwaartepunt van een klasse weergeeft corresponderend met een verandering in taxonsamenstelling. 


\subsection{Bemonsteringsinspanning en kosten}

De inspanning die nodig was voor een QSM monster lag een stuk lager dan voor een KRW monster (Tabel 8).

Tabel 8: Gemiddelde inspanning bemonstering, uitzoeken en determinatie van de QuickScan Macrofauna (QSM) monsters ten opzichte van reguliere KRW monsters.

\begin{tabular}{|l|l|l|}
\hline \multirow{2}{*}{ Onderdeel } & \multicolumn{2}{|l|}{ Verwerkingstijd per methode (uur) } \\
\cline { 2 - 3 } & KRW & QSM \\
\hline Bemonstering & 2.25 & 1.5 \\
\hline Uitzoeken & 3.45 & 1 \\
\hline Determinatie & 8 & 0.45 \\
\hline & & \\
\hline Tijd totaal (uur) & 13.7 & 2.95 \\
\hline kosten $(€)$ & 1235.74 & 266.09 \\
\hline
\end{tabular}




\section{Conclusies en aanbevelingen}

De QuickScan Macrofauna (QSM) die in maart 2018 is uitgevoerd op 24 locaties in de Sterkselsche Aa laat een duidelijke ruimtelijke spreiding van de ecologische kwaliteit zien, met een relatief slechte kwaliteit bovenstrooms en een over het algemeen goede kwaliteit benedenstrooms. De QSM heeft een ruimtelijk dekkend beeld voor het deelstroomgebied van de Sterkselsche Aa opgeleverd en geeft zo meer informatie dan de drie KRW meetpunten in de beek. Met name de plaatselijke verschillen in ecologische kwaliteit zijn interessant, dit geeft aan waar de ecologische toestand goed of redelijk is en waar niet en op welke plekken daarmee maatregelen nodig zijn. Daarnaast geeft het aan op welke knelpunten moet worden ingezet, omdat de mogelijke factoren die knelpunten veroorzaken in beeld kunnen worden gebracht. De methode is goedkoop en snel uitvoerbaar waardoor met beperkte inspanning een beeld van de ecologische toestand over het gehele waterlichaam verkregen kan worden. Het kan hiermee een goede aanvulling zijn op de KRW-methode als vorm van operationele monitoring. De KRW-methode geeft meer informatie over een meetpunt (de analyses uitgevoerd op de quickscan-data zijn uiteraard ook uitvoerbaar op de KRW-data), maar is erg kostbaar waardoor er veel minder in ruimte en tijd gemeten kan worden. Gevolg is dat op basis van één monster vaak weer minder betrouwbare uitspraken gedaan kunnen worden.

Een vergelijking tussen de QSM-scores en de KRW maatlatscores bleek lastig door het kleine aantal standaardnetmonsters en een verschil in bemonsteringsdata en voor een punt zelfs seizoen. De QSM leek over het geheel genomen kritischer dan de KRW-maatlatscores. Om een betere ijking van de KRW-maatlat met de QSM methode te doen, zouden bij een herhaling van het onderzoek meer standaardnetmonsters moeten worden genomen op hetzelfde moment als de QSM methode wordt toegepast. De aanwezigheid van indicatieve taxa voor Noord-Brabantse laaglandbeken liet zien dat met name de aanwezigheid van de kokerjuffer Halesus radiatus een goede graadmeter leek te zijn van de kwaliteit.

Door de koppeling van milieu- en habitatpreferenties aan de taxonlijsten kunnen voor de Sterkselsche Aa trajectspecifieke uitspraken worden gedaan over de aanwezigheid van stroming (oftewel het beekkarakter) van een monsterpunt, de mate organische belasting en de invloed van toxische stoffen (gewasbeschermingsmiddelen). Er zijn meer milieu- en habitatpreferenties gekoppeld aan verschillende sleutelfactoren (droogval, saliniteit, zuurgraad, temperatuur) getest, maar deze bleken niet functioneel bij de gehanteerde methodiek door een te gering onderscheidend vermogen. Dit laat zien dat er meer in detail naar de preferenties moet worden gekeken om doorontwikkeling mogelijk te maken; voldoet de huidige indeling in klassen voor alle parameters, welke alternatieven zijn er beschikbaar en hebben deze een beter onderscheidend vermogen?

Een ander belangrijk aandachtspunt is dat in de bovenloop op alle factoren onvoldoende gescoord wordt, waarbij het de vraag is wat de hierarchie en interacties zijn tussen al deze stressoren. Wat is nu bepalend of doorslaggevend? Het zou bijvoorbeeld kunnen dat de een stressor of combinatie van stressoren zo'n groot effect heeft dat op andere factoren ook slecht gescoord wordt omdat simpelweg alle indicatoren verdwenen zijn. Ook kunnen twee stressoren samen een groter effect hebben dan beide afzonderlijk. Aan dit onderdeel moet bij toekomstige quickscans meer aandacht gegeven worden. Een grotere dataset aan monsters met hierin locaties met verschillende combinaties van stressoren zou hierbij kunnen helpen om meer inzicht te krijgen in multistress-situaties.

Tenslotte zou het ook goed zijn in de toekomst de effecten van metalen mee te nemen in de quickscan, de hier gebruikte toxiciteitsindex geeft alleen indicatie voor gewasbeschermingsmiddelen (insecticiden). In het verleden loosde Philips Maarheeze bijvoorbeeld op de zijlopen Rakerloop en Kamersvenloop, welke nu nog steeds hoge concentraties cadmium en zink bevatten. Deze metalen komen uiteindelijk ook in de Sterkselsche Aa terecht. Metalen kunnen invloed uitoefenen op de samenstelling van de 
levensgemeenschap, omdat bepaalde groepen gevoeliger zijn dan andere (De Jonge et al. 2008). De door Liess et al. (2017) ontwikkelde predator-ratio, waarbij naar verhouding meer predatoren voorkomen onder omstandigheden met opgeloste metalen (o.a. zink) in het water, zou hierbij een startpunt kunnen zijn.

Wat ook meespeelt bij het beoordelen van de monsters is dat er in 2018 alleen aan- en afwezigheid is gescoord op de monsterpunten. Het is de verwachting dat het toevoegen van abundanties of abundatieklassen de beoordeling verder kan verfijnen, omdat verschuivingen in abundantieverhoudingen ook een belangrijk teken van degradatie kan zijn. Desondanks liet de multivariate analyse zien dat de QSM monsters met alleen aan- en afwezigheid bij het gehanteerde taxonomische niveau (familie, haften-steenvliegen-kokerjuffers op genus) al duidelijke patronen lieten zien. Deze patronen in taxonsamenstelling volgden in grote lijnen de patronen die in de milieuvariabelen van de monsterpunten aanwezig waren. In het voorjaar van 2019 wordt de bemonstering herhaald waarbij wel met abundantieklassen gewerkt wordt, hieruit zal duidelijk worden wat de toegevoegde waarde van het meenemen van de abundantie van de taxa is.

Tot slot kan gesteld worden dat de QSM een geschikte tool is om in te zetten bij de beekherstelen watersysteemherstelopgave die waterschap De Dommel voor de Sterkselsche Aa heeft, omdat de locaties waar ingrepen nodig zijn kunnen worden gelocaliseerd, een indruk kan worden gekregen van de knelpunten aldaar en omdat op deze manier de effectiviteit van maatregelen relatief eenvoudig kan worden geëvalueerd voor en na ingrepen in het beeksysteem. Hier komt de droogte van 2018 nog bij. Omdat onduidelijk is wat de effecten van dit extreem droge jaar is op de ecologische kwaliteit van het beeksysteem is dit een belangrijk nieuw meetdoel voor de herhaling van de bemonstering in 2019 geworden. Er kan met de QSM namelijk een beekdekkende droogte-evaluatie worden gedaan waarbij het voorjaar 2018 direct met dat van 2019 vergeleken kan worden. 


\section{Referenties}

De Jonge, M., Van de Vijver, B., Blust, R. \& Bervoets, L. (2008) Responses of aquatic organisms to metal pollution in a lowland river in Flanders: A comparison of diatoms and macroinvertebrates. Science of The Total Environment 407: 615-629.

Keizer, H.E., Gylstra, R., Verdonschot, R.C.M., \& Verdonschot, P.F.M. (2013) KRW QuickScan macrofauna 'overige wateren'. $\mathrm{H} 2 \mathrm{O}$ online.

Liess, M., Gerner, N.V., \& Kefford, B.J. (2017) Metal toxicity affects predatory stream invertebrates less than other functional feeding groups. Environmental Pollution 227: 505-512. Liess, M. \& van der Ohe, P.C. (2005) Analyzing effects of pesticides on invertebrate communities in streams. Environmental toxicology and chemistry 24: 954-965.

Verberk, W. C. E. P., Verdonschot, P. F. M., Van Haaren, T., \& Van Maanen, B. (2012) Milieuen habitatpreferenties van Nederlandse zoetwatermacrofauna (No. 2012-19). Stowa.

Verdonschot R.C.M., Verdonschot, P.F.M. (2017) Relatie KRW-doelen en macrofauna in beken in Noord-Brabant. Notitie Zoetwatersystemen, Wageningen Environmental Research, Wageningen UR, Wageningen.

Verdonschot R.C.M. \& Verdonschot P.F.M. (2010) Methodiek waardering aquatische natuurkwaliteit : ontwikkeling van graadmeters voor sloten en beken. WOt-rapport 113, Wettelijke Onderzoekstaken Natuur \& Milieu, Wageningen.

Verdonschot, P.F.M., Nijboer, R.C. (2004) Macrofauna en vegetatie van de Nederlandse beken. Een aanzet tot beoordeling van de ecologische toestand. Alterra-rapport 756, Alterra, Wageningen. 